\section{Oppløftende selvhjelpsbok om voldtekt}

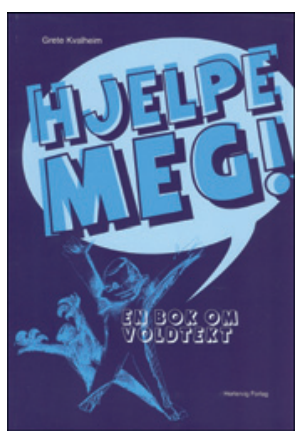

\section{Grete Kvalheim}

Hjelpe meg!

En bok om voldtekt. $169 \mathrm{~s}$, ill. Stavanger: Hertervig Akademisk, 2011. Pris NOK 250 ISBN 978-82-8216-130-5

Temaet er seksuelle overgrep. Målgruppen er fortrinnsvis dem som har vært utsatt for voldtekt og deres pårørende, men boken kan gjerne leses av leger og annet helsepersonell, politifolk, jurister og andre hjelpere.

Grete Kvalheim, grunnlegger av DIXI ressurssenter for voldtatte, har redigert, men flere kapitler er skrevet av erfarne fagpersoner som traumepsykiater, allmennlege, politietterforsker, jurist og psykolog.

Det er imponerende at Kvalheim har fått samlet slikt tverrfaglig stoff på norsk. For meg som lege var det spesielt nyttig å lese kapitlene om avhør, etterforskning og jus. Men dette er ingen lærebok i mottak av voldtektsofre for helsepersonell, til det er kapitlet om helseundersøkelsen etter voldtekt for overfladisk og generelt beskrevet. En slik gjennomgang mangler i Norge i dag. Bortsett fra veilederen for helsepersonell fra 2007 (1) og et kapittel i den norske læreboken i rettsmedisin (2), er det ikke kommet noen fagbok om voldtekt på norsk siden 1992 (3).

Den praktiske paperbacken er rikt illustrert. Illustrasjonene er i blåtoner og svart-hvitt. De oppleves enkle, symbolske og gjennomgående positive. Allerede på omslaget ser vi et oppreist menneske med energi.

Boken bærer preg av de ulike forfatternes stiler og uttrykksmåter. Kvalheim behersker med letthet det folkelige, lettleste språket. Imidlertid er kapitlet om krisereaksjoner altfor teoretisk skrevet, dette til tross for liste med ordforklaringer. Rammene med definisjoner på faguttrykk er nyttige, og noen forfattere gir referanser.

Voldtektsutvalget kom med forslag om gratis psykologhjelp etter voldtekt (4). Det påpekes hvor viktig nettverket rundt den utsatte er, og at kriseavlastende støtteterapi benyttes ved mange overgrepsmottak i Norge i dag. Juristen påpeker at man har rett til gratis bistandsadvokat i forkant av en eventuell anmeldelse, beskriver ulike erstatningsordninger og forklarer hva henleggelse innebærer, at dette ikke nødvendigvis betyr at fornærmede ikke er blitt trodd! Hun argumenterer for å anmelde til politiet selv om saken skulle ende med henleggelse. Psykologen skriver bra om straff og hevn. Imidlertid nevnes ikke konfliktrådets «tilrettelagt dialog»-konsept (restorative justice) eller andre alternativer til straff som for eksempel er under utprøving i Trondheim. Jeg savner også bidrag fra barnelege og statsadvokat i denne ellers nokså vidtfavnende boken.

I motsetning til Kvalheims forrige bok om hennes egen voldtektshistorie, oppfattes dette som noe mer fagorientert litteratur, krydret med pasienthistorier. Mange frivillige organisasjoner med deres nettsider presenteres til slutt.

Som grunnlag for undervisning er boken velegnet, og jeg anbefaler at alle landets overgrepsmottak kjøper den inn. Den har gitt nyttige innspill til meg som helsehjelper i voldtektssaker, og jeg vil trygt anbefale den til mine pasienter, kolleger og andre som arbeider med temaet.

\section{Cecilie Hagemann}

Institutt for samfunnsmedisin

Norges teknisk-naturvitenskapelige universitet

\footnotetext{
Litteratur

1. Overgrepsmottak: Veileder for helsetjenesten. Oslo: Sosial- og helsedirektoratet, 2007.
}

2. Rognum TO, red. Lærebok i rettsmedisin. Oslo: Gyldendal akademisk; 2010.

3. Bang L, Hydle I. Mishandling og seksuelle overgrep: legens faglige oppgaver i helse og rettsvesenet. Oslo: TANO, 1992.

4. Fra ord til handling. Bekjempelse av voldtekt krever handling. Oslo: Justisog politidepartementet, 2008

\section{Leseverdig om stemmehøring}

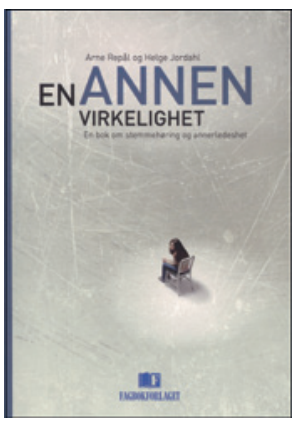

\section{Arne Repål, Helge Jordahl \\ En annen virkelighet}

En bok om stemmehøring og annerledeshet.

147 s. Bergen: Fagbokforlaget, 2011.

Pris NOK 229

ISBN 978-82-450-1083-1

Det er tre målgrupper: stemmehørere, helsepersonell og pårørende. Etter min oppfatning treffer denne utgivelsen målgruppene bra. Begge forfatterne er psykologer, og psykologene har antagelig større kompetanse på normalvarianter enn psykiatere tradisjonelt har. Leseren introduseres for gradvise overganger fra uskyldige normalfenomener til alvorlige, plagsomme stemmer som påvirker atferden til stemmehøreren.

Boken har fire hoveddeler. Første del omhandler fornuft og følelser, andre del stemmehøring, og i tredje del tar forfatterne for seg hvem som kan hjelpe den som er plaget av stemmehøring. Den fjerde og siste delen inneholder omtaler av filmer og bøker, i tillegg til henvisninger om temaet.

Forfatterne ønsker å bryte ned skillet mellom «oss» og «dem». De hevder at 2-4 prosent av normalbefolkningen regelmessig hører stemmer. Hørselshallusinasjoner omtales konsekvent som stemmehøring, og inkluderer alle varianter fra hypnagoge fenomener til imperative stemmer.

Språket er godt. Kliniske vignetter er rammet inn i bokser og illustrerer godt innholdet for øvrig. I tillegg har boken mange morsomme småhistorier om blant annet hvordan feiloppfatninger oppstår, eller når sterk mistenksomhet kan være på sin plass.

Kognitiv tenkning preger tilnærmingen i boken. Dette blir særlig tydelig i avsnittet om behandling. Spørsmålene stemmehøreren kan stille seg selv, eller bli stilt av behandleren, er gode, respektfulle og utfordrende. Men avsnittet inneholder også gode anvisninger om når medikamenter kan være på sin plass, og om viktigheten av å samarbeide med legen om medisinsk behandling.

Jeg synes forfatterne leverer det de intenderer i innledningen. Det er tydelig at forfatterne har bred klinisk erfaring, og jeg synes de oppnår å forstyrre skillet mellom «oss» og «dem». Skulle jeg være riktig pirkete, så er det et par trykkfeil, og den virker kan hende noe overpedagogisk her og der, men dette er bare små skjønnhetsfeil. I det store og hele en leseverdig bok for alle de tre målgruppene.

\section{Synnøve Bratlie}

Dr. Bratlies spesialistpraksis

Oslo 